\title{
Piscine myocarditis virus (PMCV) in wild Atlantic salmon Salmo salar
}

\author{
Åse Helen Garseth ${ }^{1, *}$, Eirik Biering ${ }^{1}$, Torstein Tengs ${ }^{2}$ \\ ${ }^{1}$ Norwegian Veterinary Institute, Tungasletta 2, 7047 Trondheim, Norway \\ ${ }^{2}$ Norwegian Veterinary Institute, Section for Virology, Ullevaalsveien 68, 0454 Oslo, Norway
}

\begin{abstract}
Cardiomyopathy syndrome (CMS) is a severe cardiac disease of sea-farmed Atlantic salmon Salmo salar L., but CMS-like lesions have also been found in wild Atlantic salmon. In 2010 a double-stranded RNA virus of the Totiviridae family, provisionally named piscine myocarditis virus (PMCV), was described as the causative agent of CMS. In the present paper we report the first detection of PMCV in wild Atlantic salmon. The study is based on screening of 797 wild Atlantic salmon by real-time RT-PCR. The samples were collected from 35 different rivers along the coast of Norway, and all individuals included in the study were classified as wild, based on visual appearance and scale reading. Two samples tested positive during PCR analysis, and the results were confirmed by sequencing.
\end{abstract}

KEY WORDS: Piscine myocarditis virus · Wild Atlantic salmon · PCR $\cdot$ CMS · Disease interaction Resale or republication not permitted without written consent of the publisher

\section{INTRODUCTION}

Cardiomyopathy syndrome (CMS) is an inflammatory heart disease, primarily affecting farmed Atlantic salmon, Salmo salar L. The disease was first detected in Norway in 1985 (Amin \& Trasti 1988) and has since been diagnosed in farmed Atlantic salmon at the Faeroe Islands (Poppe \& Sande 1994, Poppe \& Seierstad 2003) and in Scotland (Rodger \& Turnbull 2000). A disease resembling CMS has also been described from British Columbia, Canada (Brocklebank \& Raverty 2002). In 2003 the first cases of CMS-like lesions in wild Atlantic salmon were reported (Poppe \& Seierstad 2003).

CMS is most commonly diagnosed during the late sea-water phase in farmed salmon and is thus a disease causing considerable losses for the affected farms and the industry (Brun et al. 2003). The clinical features of CMS vary from acute death without prior clinical signs to elevated mortality with nonspecific signs such as impaired or abnormal swimming behaviour. The CMS diagnosis has so far been based on detection of characteristic inflammation and degeneration of spongy myocardium in the atrium and ventricle during histopathological examination. Secondary findings are multifocal liver necrosis, indicative of chronic passive congestive circulatory disturbances (Amin \& Trasti 1988, Ferguson et al. 1990, Fritsvold et al. 2009).

Several hypotheses on the aetiology of CMS have been presented but even in the first description a viral aetiology was suggested (Amin \& Trasti 1988). This was based on the presence of eosinophilic inclusions in nuclei of myocardial fibres in the vicinity of degenerated areas. Experimental transmission studies have supported this hypothesis (Bruno \& Noguera 2009, Fritsvold et al. 2009), and in 2010 a doublestranded RNA virus tentatively of the Totiviridae family was described as the causative agent of CMS (Løvoll et al. 2010, Haugland et al. 2011).

Several authors have expressed concern about CMS as a potential threat to wild Atlantic salmon populations (Rodger \& Turnbull 2000, Poppe \& Seierstad 2003), and the identification of a causative agent 
has made it possible to screen wild and farmed populations. The aim of the current study was to determine if PMCV is present in wild Atlantic salmon populations and to evaluate the potential role of wild salmon as a virus reservoir. The study is based on screening of wild Atlantic salmon by real-time RT$\mathrm{PCR}$, and we report the first cases of PMCV in wild Atlantic salmon.

\section{MATERIALS AND METHODS}

\section{Study sample}

Our sample set included 797 wild Atlantic salmon caught in 35 Norwegian rivers during the period 2007 to 2009 (Table 1). The sample set is a subset of the sample collection described by Garseth et al. (Garseth et al. 2012). Out of the total, 736 salmon were caught as brood fish by local stock enhancement hatcheries or as part of the restocking activities of the Norwegian gene bank programme for wild Atlantic salmon (http://english-test.dirnat.no/content. ap?thisId=1003550\&language=3). These brood fish were caught in 31 different rivers by rod, electrofishing or net during September to November and were kept in freshwater tanks onshore or in cages in the rivers until stripping. Samples from brood fish were collected by authorised fish health personnel during routine post mortem examination and health control. Another 61 salmon were caught in 4 rivers during recreational and commercial fishing by rod and bag nets in 2008. The purpose of this sampling was disease surveillance in wild populations during infectious salmon anemia (Nord-Trøndelag) and viral hemorrhagic septicemia (Møre \& Romsdal) outbreaks in aquaculture sites in the vicinity of the rivers. Fish caught during recreational and commercial fishing were euthanized immediately and sampled by lay personnel trained by fish health professionals from the Norwegian Veterinary Institute (NVI). Head-kidney samples were fixed in RNAlater (Ambion) and sent frozen on ice to the NVI for further analysis.

All salmon, regardless of origin, were subjected to extensive registration and scale reading (Antere \& Ikonen 1983, Lund \& Hansen 1991, Fiske et al. 2004). Individual information, such as origin (river), classification based on scale reading, sex, body length, weight, smolt-age, winter-sea-age and post mortem findings were recorded in a database. Salmon classified as released from stock enhancement hatcheries (cultivated salmon), escaped from aquaculture facilities or those that could not be classified during scale
Table 1. Salmo salar. Study sample, consisting of 797 wild Atlantic salmon caught in 35 Norwegian rivers from 2007 to 2009

\begin{tabular}{|c|c|c|c|c|c|}
\hline \multirow[t]{2}{*}{ County } & \multirow[t]{2}{*}{ River } & \multicolumn{3}{|c|}{- Year -} & \multirow[t]{2}{*}{ Total } \\
\hline & & 2007 & 2008 & 2009 & \\
\hline Finnmark & Alta & 6 & 14 & 14 & 34 \\
\hline Troms & Skibotnelva & 0 & 1 & 2 & 3 \\
\hline \multirow{6}{*}{ Nordland } & Drevja & 0 & 1 & 8 & 9 \\
\hline & Fusta & 0 & 7 & 7 & 14 \\
\hline & Halsanelva & 0 & 14 & 7 & 21 \\
\hline & Hestdalselva & 0 & 17 & 16 & 33 \\
\hline & Skjoma & 0 & 0 & 7 & 7 \\
\hline & Vefsna & 0 & 4 & 4 & 8 \\
\hline \multirow{5}{*}{$\begin{array}{l}\text { Nord } \\
\text { Trøndelag }\end{array}$} & Mossa & 2 & 5 & 5 & 12 \\
\hline & Namsen $^{\mathrm{a}}$ & 0 & 16 & 0 & 16 \\
\hline & Steinkjerelva & 0 & 23 & 0 & 23 \\
\hline & Stjørdalselva & 19 & 24 & 28 & 71 \\
\hline & Øyensåa $^{a}$ & 0 & 16 & 0 & 16 \\
\hline \multirow{2}{*}{$\begin{array}{l}\text { Sør } \\
\text { Trøndelag }\end{array}$} & Gaula & 14 & 10 & 15 & 39 \\
\hline & Nidelva & 9 & 14 & 11 & 34 \\
\hline \multirow{8}{*}{$\begin{array}{l}\text { Møre \& } \\
\text { Romsdal }\end{array}$} & Batnfjordselva & 1 & 0 & 0 & 1 \\
\hline & Bævra & 0 & 0 & 7 & 7 \\
\hline & Driva & 5 & 3 & 10 & 18 \\
\hline & Eidsdalselva $^{\mathrm{a}}$ & 0 & 16 & 0 & 16 \\
\hline & Eira & 6 & 7 & 26 & 39 \\
\hline & Surna & 13 & 20 & 24 & 57 \\
\hline & Toåa & 2 & 7 & 8 & 17 \\
\hline & Valldalselva $^{\mathrm{a}}$ & 0 & 13 & 0 & 13 \\
\hline \multirow{6}{*}{$\begin{array}{l}\text { Sogn \& } \\
\text { Fjordane }\end{array}$} & Fortunselva & 0 & 3 & 2 & 5 \\
\hline & Jølstra & 0 & 13 & 0 & 13 \\
\hline & Lærdalselva & 5 & 3 & 5 & 13 \\
\hline & Nausta & 0 & 14 & 0 & 14 \\
\hline & Vikja & 9 & 34 & 13 & 56 \\
\hline & Årøy & 10 & 3 & 10 & 23 \\
\hline \multirow[t]{4}{*}{ Hordaland } & Eio/Bjoreio & 0 & 6 & 8 & 14 \\
\hline & Ekso & 7 & 14 & 0 & 21 \\
\hline & Etne & 0 & 0 & 18 & 18 \\
\hline & Vosso & 0 & 8 & 18 & 26 \\
\hline Vest-Agder & Mandalselva & 9 & 0 & 34 & 43 \\
\hline Aust-Agder & Storelva Holt & 14 & 11 & 18 & 43 \\
\hline Total & & 131 & 341 & 325 & 797 \\
\hline
\end{tabular}

reading were omitted from the study. Hence, all 797 salmon included in this study were classified as wild.

\section{RNA extraction, real-time RT-PCR and sequencing}

RNA was isolated from head kidney tissue and analysed by use of a PMCV-specific real-time RTPCR assay (Løvoll et al. 2010). RNA was extracted as described in Garseth et al. (2012). Approximately $20 \mathrm{mg}$ of tissue was homogenised in Lysing Matrix D- 
containers (MP Biomedicals GmbH) with $200 \mu \mathrm{l}$ lysis/binding solution (MagMAX-96 Total RNA Isolation Kit, Ambion) and 1,4 $\mu \mathrm{l} \quad \beta$-mercaptoetanol (Sigma-Aldrich Chemie $\mathrm{GmbH}$ ) by use of a rotor stator homogenizer (Bio-Rad Laboratories). The RNA isolation kit was also used in the following steps of RNA isolation and the extraction was performed according to the manufacturers' recommendations. To perform the magnetic based separation, a KingFisher (Labsystems Oy) was used. After elution, the RNA concentration and purity was measured by use of a NanoDrop ND-1000 spectrophotometer (NanoDrop Technologies). All samples had OD260/280 ratios between 1.8 and 2.2. Between 500 and $1000 \mathrm{ng}$ RNA was added to the reaction and the real-time RT PCR protocol was performed with forward primer TTC CAA ACA ATT CGA GAA GCG, reverse primer GTA GCC AAG TGG GAG AAA GCT and probe FAM-CTG GCC ACC ACT TCG A- MGBNFQ (all written in 5' to 3' direction). The Qiagen OneStep RT-PCR kit (Qiagen) was used with primer concentrations of $500 \mathrm{nM}$, probe concentration $300 \mathrm{nM}$ and the following PCR cycle: $30 \mathrm{~min}$ at $50^{\circ} \mathrm{C}$ (reverse transcription), $15 \mathrm{~min}$ at $95^{\circ} \mathrm{C}$ (inactivation of reverse transcriptase and activation of hotstart), followed by 45 cycles of $15 \mathrm{~s}$ at $94^{\circ} \mathrm{C}$ (template denaturation) and $1 \mathrm{~min}$ at $60^{\circ} \mathrm{C}$ (primer annealing and elongation). Samples with threshold cycle $\left(C_{\mathrm{t}}\right)$ values below 40 and an exponential curve were regarded as positive, and samples with $C_{\mathrm{t}}$ values equal to or higher than 40 were regarded as negative.

Samples that were PCR-positive were further investigated by sequencing. Partial sequences for all 3 open reading frames (ORFs) in the PMCV genome (Haugland et al. 2011) were derived using direct sequencing of PCR products. The Qiagen OneStep RT-PCR kit was used with final primer concentrations $600 \mathrm{nM}$ and the following PCR cycle: $30 \mathrm{~min}$ at $50^{\circ} \mathrm{C}$ (reverse transcription), $15 \mathrm{~min}$ at $95^{\circ} \mathrm{C}$ (inactivation of reverse transcriptase and activation of hotstart PCR DNA polymerase), $30 \mathrm{~s}$ at $94^{\circ} \mathrm{C}$ (template denaturation), $1 \mathrm{~min}$ at $55^{\circ} \mathrm{C}$ (primer annealing), $1 \mathrm{~min}$ at $72^{\circ} \mathrm{C}$ (primer elongation; 45 cycles total) and a final elongation step $\left(3 \mathrm{~min}\right.$ at $\left.72^{\circ} \mathrm{C}\right)$. ORF2 (RNA- dependent RNA polymerase; GenBank accession NC_015639) was amplified using the primers described in Tengs \& Böckerman (2012). ORF1 and ORF3 (coat/structural proteins) PCRs were performed using the newly designed primers PMCV ORF1f (CGA CGA CCG AAC AAT TGG AC) in combination with PMCV_ORF1r (CCT CTC ATC ATG GAC TCA GGT TG) and PMCV_ORF3f (AAT GGT GTTT GTG CAC TGC AG) combined with PMCV ORF3r (TGG AGG GCG TGG CTC TAA C), respectively. Excess nucleotides and unincorporated primers were removed using ExoSAP-IT (GE Healthcare), and purified PCR products were sequenced according to the method of Sanger using the PCR primers.

\section{RESULTS AND DISCUSSION}

In studies concerning wild salmonid populations, having some means of distinguishing wild subjects from subjects escaped from aquaculture sites is important. In Poppe \& Seierstads (2003) on CMS-related lesions in 4 wild Atlantic salmon, 2 of the salmon were among 50 salmon caught in the River Namsen and 2 were part of a catch of 9 salmon that were caught in traps outside the coast of Nordland. Salmon caught in Namsen were classified as wild based on external appearance and scale reading, while salmon caught in Nordland were assumed to be wild based on external appearance and lack of post-immunisation peritonitis. In the current study all salmon were classified as wild based on both external characteristics and scale reading. In addition, the fish health personnel that performed the post mortem examinations did not report post-immunisation peritonitis in the tested subjects.

A total of 797 wild Atlantic salmon were tested and 2 of these were PMCV-positive (Table 2) with $C_{\mathrm{t}}$ values of 24.9 and 29.2. Both samples came from brood fish, but neither of them displayed gross pathology resembling CMS. This corresponds to $0.25 \%$ of our samples. Although our samples had been collected from all along the Norwegian coastline, the 2 positive samples came from locations that were in proximity to each other (Fig. 1).

Table 2. Salmo salar. Individual information on the 2 piscine myocarditis virus (PMCV)-positive wild Atlantic salmon

\begin{tabular}{|c|c|c|c|c|c|c|c|c|c|}
\hline \multirow[t]{2}{*}{ Fish ID } & \multirow[t]{2}{*}{ River } & \multirow[t]{2}{*}{ Year } & \multirow[t]{2}{*}{ Sex } & \multirow{2}{*}{ Spawning } & \multicolumn{2}{|c|}{ Age (yr) } & \multirow{2}{*}{$\begin{array}{l}\text { Length } \\
\text { (cm) }\end{array}$} & \multirow{2}{*}{$\begin{array}{l}\text { Weight } \\
(\mathrm{kg})\end{array}$} & \multirow[t]{2}{*}{ Post mortem findings } \\
\hline & & & & & Smolt & Winter-sea & & & \\
\hline 708 & Nausta & 2008 & M & 5 & 3 & 2 & 73 & - & $\begin{array}{l}\text { Anisakis sp., Eubothrium sp., } \\
\text { Salmincola salmoneus }\end{array}$ \\
\hline 1198 & Årøy & 2007 & M & 6 & 3 & 3 & 119 & 15 & Saprolegnia affected wounds \\
\hline
\end{tabular}




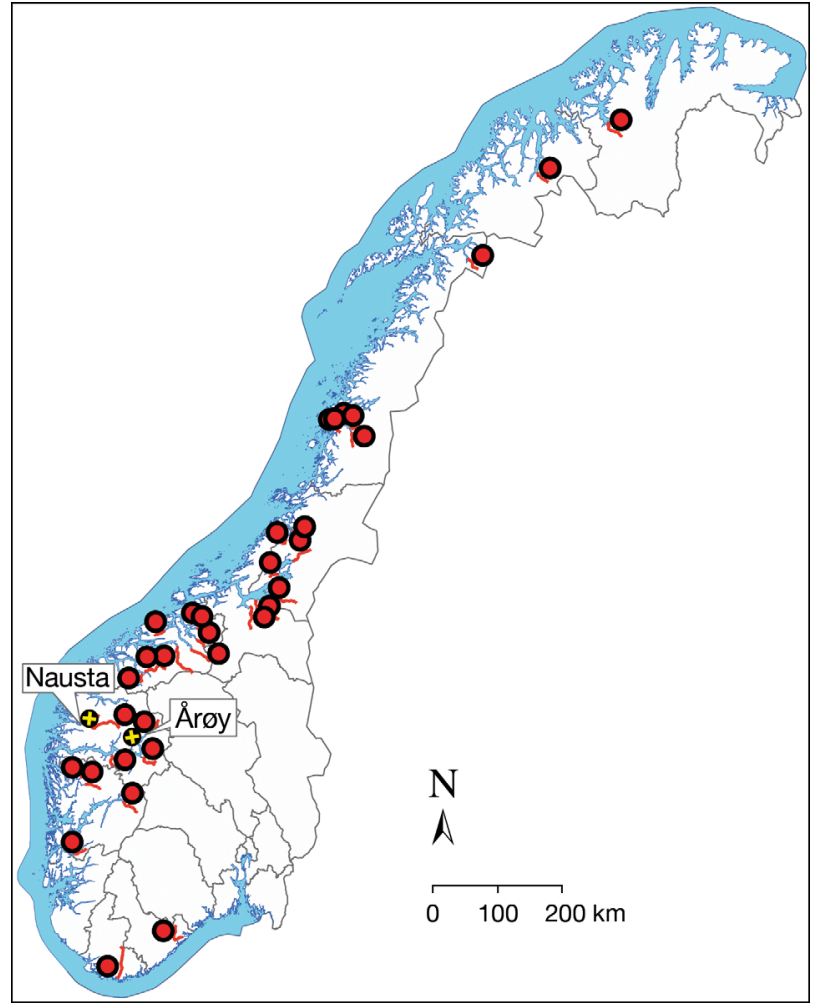

Fig. 1. Location of rivers in Norway where fish were sampled (0). Piscine myocarditis virus (PMCV) was detected in Nausta and Årøy $(\bullet)$

The tissue distribution of PMCV in infected salmon is not completely mapped. Thus, other organs than head-kidney could be more suitable for screening (Løvoll et al. 2010, Wiik-Nielsen et al. 2012) and give different results. In addition, most of the sampled fish were returning spawners, and the virus may be more prevalent in other life history stages of wild salmon.

A relevant question is whether the presence of PMCV in these samples indicates a potential viral reservoir in wild salmon (relevant for CMS in fish farms), or whether these have fish have simply been infected by being in proximity to either infected wild marine fish or PMCV-positive, farmed fish populations. During real-time RT-PCR screening of more than 30 marine fish species Böckerman et al. (2011) detected PMCV in Atlantic argentine Argentina silus Ascanius. However molecular epidemiology indicates that PMCV found in A. silus represents a distinct genotype compared to PMCV detected in farmed Atlantic salmon (Tengs \& Böckerman 2012). According to the records of NVI, CMS was diagnosed in May 2007 in fish from a sea farm in the outlet of the Sognefjord where the River Årøy is situated. The local fish health service describes this as an insignifi- cant incident with regards to morbidity and mortality. There are no NVI-records of CMS in sea-farms in the Førdefjord outside the inlet of River Nausta. The local fish health service has suspected a CMS diagnosis in several sea-farms during the period 2006 to 2008, but the outbreaks were eventually diagnosed as heart and skeletal muscle inflammation (HSMI) or 'not conclusive'. Thus, there is no clear evidence of a high infection pressure of PMCV from farmed salmon in these areas at the relevant time.

Sequencing revealed that both isolates from wild salmon were $>99 \%$ similar to the PMCV genome sequence reported by Haugland et al. (2011) (GenBank accession numbers JQ745675-JQ745680). Using this genome as a reference, Isolate $1198 \mathrm{had}$ a partial ORF3 sequence that was identical to the reference genome, but in both isolates a small number of unique single nucleotide differences were detected in the other 2 ORFs. Little is known about the molecular epidemiology of PMCV, but when more data become available it might be possible to determine whether the genotypes we have encountered represent 'wild' populations of the virus or whether it is more likely that the fish were infected by PMCVpositive farmed salmon.

Studies of farmed salmon indicate that viral RNA from PMCV can be present several months before a CMS outbreak (Wiik-Nielsen et al. 2012) but also that presence of PMCV is closely linked to development of disease (Løvoll et al. 2010, Haugland et al. 2011). CMS is a severe condition affecting the myocardium and one would expect wild fish with CMS to either die or to have reduced cardiovascular capacity, thus being less capable of returning to rivers where the sampling was conducted. Hence, the detected occurrence of PMCV in wild brood fish may be an underestimate. The results from the current study indicate a limited occurrence of PMCV in wild adult migrating Atlantic salmon, and wild Atlantic salmon at this life history stage seem unlikely to play a major role as a reservoir for the virus.

Acknowledgements. The authors thank the Norwegian Gene bank for wild Atlantic salmon (The Directorate for Nature Management) and members of the Health service for stock enhancement hatcheries. Special thanks to I. Kaada for valuable information regarding PMCV-positive salmon from River Nausta and regarding CMS-status in Førdefjorden. Special thanks also to M. Vigerust for technical assistance and to A. Tarpai for construction of Fig. 1. The project was financed by The Directorate for Nature Management, Marine Harvest, Aqua Gen and the Norwegian Veterinary Institute (internal project 2011022). 


\section{LITERATURE CITED}

Amin A, Trasti J (1988) Endomyocarditis in Atlantic salmon in Norwegian seafarms. Bull Eur Assoc Fish Pathol 8:70-71

Antere I, Ikonen E (1983) A method of distinguishing wild salmon from those originating from fish farms on the basis of scale structure. ICES J Mar Sci 26:1-7

Böckerman I, Wiik-Nielsen CR, Sindre H, Johansen R, Tengs T (2011) Prevalence of piscine myocarditis virus (PMCV) in marine fish species. J Dish Dis 34:955-957

Brocklebank J, Raverty S (2002) Sudden mortality caused by cardiac deformities following seining of preharvest farmed Atlantic salmon (Salmo salar) and by cardiomyopathy of postintraperitoneally vaccinated Atlantic salmon parr in British Columbia. Can Vet J 43:129-130

Brun E, Poppe T, Skrudland A, Jarp J (2003) Cardiomyopathy syndrome in farmed Atlantic salmon Salmo salar: occurrence and direct financial losses for Norwegian aquaculture. Dis Aquat Org 56:241-247

Bruno DW, Noguera PA (2009) Comparative experimental transmission of cardiomyopathy syndrome (CMS) in Atlantic salmon Salmo salar. Dis Aquat Org 87:235-242

Ferguson HW, Poppe T, Speare DJ (1990) Cardiomyopathy in farmed Norwegian salmon. Dis Aquat Org 8:225-231

Fiske P, Lund RA, Hansen LP (2004) Identifying fish farm escapees. In: Cadrin SX, Friedland KD, Waldman JR (eds) Stock identification methods: applications in fishery science. Elsevier, Amsterdam, p 659-680

Fritsvold C, Kongtorp RT, Taksdal T, Ørpetveit I, Heum M, Poppe TT (2009) Experimental transmission of cardiomyopathy syndrome (CMS) in Atlantic salmon Salmo salar. Dis Aquat Org 87:225-234

Editorial responsibility: Gregory Chinchar,

Jackson, Mississippi, USA
Garseth ÅH, Fritsvold C, Opheim M, Skjerve E, Biering E (2012) Piscine reovirus (PRV) in wild Atlantic salmon, Salmo salar L and seatrout, Salmo trutta L. in Norway. J Fish Dis doi:10.1111/j.1365-2761.2012.01450.x

Haugland $\varnothing$, Mikalsen AB, Nilsen P, Lindmo K and others (2011) Cardiomyopathy syndrome of Atlantic salmon (Salmo salar L.) is caused by a double-stranded RNA virus of the Totiviridae family. J Virol 85:5275-5286

Løvoll M, Wiik-Nielsen J, Grove S, Wiik-Nielsen CR and others (2010) A novel totivirus and piscine reovirus (PRV) in Atlantic salmon (Salmo salar) with cardiomyopathy syndrome (CMS). Virol J 7:309

Lund RA, Hansen LP (1991) Identification of wild and reared Atlantic salmon, Salmo salar L., using scale characters. Aquacult Fish Manag 22:499-508

Poppe TT, Sande RD (1994) Cardiomyopathy in farmed Atlantic salmon: a review, introducing an ultrasound technique for clinical examination. Norwegian School of Veterinary Science, Oslo

> Poppe TT, Seierstad SL (2003) First description of cardiomyopathy syndrome (CMS)-related lesions in wild Atlantic salmon Salmo salar in Norway. Dis Aquat Org $56: 87-88$

Rodger H, Turnbull T (2000) Cardiomyopathy syndrome in farmed Scottish salmon. Vet Rec 146:500-501

Tengs T, Böckerman I (2012) A strain of piscine myocarditis virus (PMCV) infecting Atlantic argentine Argentina silus (Ascanius). J Fish Dis 35:545-547

Wiik-Nielsen CR, Ski PMR, Aunsmo A, Løvoll M (2012) Prevalence of viral RNA from piscine reovirus and piscine myocarditis virus in Atlantic salmon, Salmo salar L., broodfish and progeny. J Fish Dis 35:169-171

Submitted: March 8, 2012; Accepted: September 10, 2012 Proofs received from author(s): November 30, 2012 